Article

\title{
Constructing the "Competent" Pupil: Optimizing Human Futures Through Testing?
}

\author{
Stephan Dahmen \\ Faculty for Educational Science, Bielefeld University, Germany; E-Mail: stephan.dahmen@uni-bielefeld.de
}

Submitted: 30 March 2021 | Accepted: 19 May 2021 | Published: 16 September 2021

\begin{abstract}
In the last decade, the German transition system has witnessed the large-scale introduction of so-called "analysis of potentials" (Potenzialanalysen) in secondary compulsory schooling. In most German Länder, 8th graders must participate in a two-day assessment center which combines psychometric testing with observations of their social and professional competencies in pre-specified tasks. The programmatic aim of these assessments is to "introduce pupils early to choosing a job" (Bundesministerium für Bildung und Forschung [BMBF], 2017, p. 2) as well as to enhance the propensity of pupils to "take responsibility for their own future" (BMBF, 2017, p. 9). In the context of the German school-to-work system, the introduction of these new forms of diagnostics bear witness to a new preventive political rationality that aims at reducing the entry age into upper secondary education, reduce the recourse to so-called "transition measures" and optimizing transitions into an apprenticeship market that is characterized by structural inequalities and "mismatch" between pupils' job aspirations and the offers in apprenticeship places. However, little is known on the role of competency testing devices for the construction of further trajectories and aspirations and their role in the reproduction of inequalities in transitions from school to work. Based on an in-depth analysis of policy documents and competency profiles (the documents handed out to the pupils after undergoing testing), the article reconstructs the political rationale for the introduction of the so-called Potenzialanalysen. Based on a Foucauldian framework, we show how pupils are constructed as "competent" subjects. We show that competency assessments are part and parcel of a political rationality that aims at the promotion of a specific (future-oriented, optimized, self-regulated) relation to one's own biographical future on the side of the pupils. Our results demonstrate that competency profiles construct the process of choosing a job as an individualized project of the self and that they invisibilize structural barriers and power relations. In doing so, competency assessments potentially contribute to the reproduction of inequalities in post-secondary education through delegating "cooling out" processes from institutional gatekeepers to the interiority of persons.
\end{abstract}

\section{Keywords}

career guidance; competencies; education policy; Germany; governmentality studies; institutional ethnography; school-to-work-transitions; subjectivation; testing; vocational education and training

\section{Issue}

This article is part of the issue "Education, Politics, Inequalities: Current Dynamics and Perspectives" edited by Kenneth Horvath (University of Lucerne, Switzerland) and Regula Julia Leemann (University of Teacher Education FHNW, Switzerland / University of Basel, Switzerland).

(C) 2021 by the author; licensee Cogitatio (Lisbon, Portugal). This article is licensed under a Creative Commons Attribution 4.0 International License (CC BY).

\section{Introduction}

Despite a long history of critical debates on the pitfalls and problems of testing, standardized testing is proliferating in the world of education. The promise of testing in education is to help the just and effective channeling of students according to ability and to identify those students that are particularly gifted or that require specific support. In addition, testing plays an increasing role for the management and the measurement of performance of individuals, groups, and whole educational systems. However, critical perspectives on testing have highlighted that tests are concerned with a socially constructed, rather than with some 
independently existing reality. They stress that testing itself is a deeply social, value-laden activity (Egbert, 2018) and that testing often serves a multitude of purposes and interests (Stobart, 2008). Tests do not simply measure an independently existing reality but "create what they are supposed to measure" (Hanson, 1994, p. 74; see also Hacking, 2004). The present study empirically unfolds the political rationalities and potential effects of testing through focusing on the recent large-scale introduction of competency testing in secondary compulsory schooling in Germany. Since 2010, so-called Potenzialanalysen (a semi-standardized competence assessment for 8th graders according to German-wide standards) have been implemented with the aim to reduce the number of pupils without a vocational degree and to smoothen their transition to work.

The purpose of this article is twofold. First, it aims to critically examine the political rationale that led to the introduction of Potenzialanalysen and to contextualize it within recurrent debates of the German transition system. Secondly, it aims at revealing the performative power of competency testing through an in-depth analysis of competency profiles (the documents handed out to pupils after performing a Potenzialanalyse). Drawing on theories of subjectivation and on actor-network theory, this article mobilizes the notion of textually mediated subjectivation devices for analyzing how competency assessments construct a specific, reflexive, and future oriented pupil with realistic job aspirations. With this in mind, we aim to address the following research questions: What realities do the competency profiles construct, and how does it configure, describe, and evaluate the pupils? How are further trajectories and aspirations constructed in the competency profiles and what are the implications for social inequalities? How is the federal policy of a wide-scale introduction of competency assessments translated and made durable on the level of the documents and artifacts used in the assessment procedure?

The research study contributes to the existing literature in several ways: Literature in the field of governmentality studies has described tests as technologies that enforce specific regimes of visibility that "performatively produce what they pretend to measure" (Lemke, 2004 , p. 267) and aim at the formation of a specific, selfreflective individuality (Bröckling, 2015). Nevertheless, little is known about the use of such devices for the construction of further trajectories and aspirations and their role in the reproduction of inequalities in transitions from school to work. In applying the framework of subjectivation analysis to this field, the study aims to contribute to the emerging field of "empirical subjectivation research" (Bosančić et al., 2019). Research that focusses on vocational choice processes in the transition from school to work (Preite, 2019; Walther, 2015) has highlighted the role of "cooling out" processes for the pedagogical construction of (realistic) career perspectives. This article adds to that literature by show- ing that competency assessments constitute a central tool for the identity work involved in aligning the space of subjective possibilities to the structurally probable. Last but not least, the article contributes to the literature on documents and documentation (Alasuutari et al., 2020; Kelle et al., 2015) that attempts to theorize the role of non-human actors and artifacts and socio-material arrangements for pedagogical practices. It attempts to describe how a specific policy translates into a network of action in which the artifact competency profile constitutes a powerful and creative intermediary that mobilizes a whole series of people and events. The analysis is based on a documentary analysis of policy documents and working papers by the federal government accompanying the introduction of Potenzialanalysen and on the basis of competency profiles of the most commonly used competency assessment procedures. The analysis does not aim to reveal the differences between the procedures, but rather to focus on how the guidelines by the federal state have been locally translated and implemented.

The article is structured as follows. A first part introduces the specificities of the German educational system and reviews the political rationale for the introduction of competency assessments. The next section introduces the concept of textually mediated subjectivation devices from the background of governmentality studies and actor-network theory. Following the methodology section, we successively present how the competency profiles establish a specific regime of visibility that is put to use, both for the control, screening, and improvement of the human capital of individuals by government actors, and for fostering processes of biographic selfoptimization of pupils. We conclude with a reflection on the role of new forms of testing for the reproduction of inequalities and cooling out processes in education.

\section{Optimizing Transitions through Testing?}

In Germany, nearly $50 \%$ of school leavers enter a dual apprenticeship after secondary schooling. While the German apprenticeship system is often touted for its low youth unemployment rates and a low skills mismatch (Piopiunik \& Ryan, 2001), particularly for pupils with lower educational credentials, the transition from school to apprenticeships constitutes a bottleneck for the access to secondary education (Gaupp et al., 2011; Kohlrausch \& Solga, 2012). As a collective skill formation system, the access to apprenticeship positions is regulated by means of an apprenticeship market-that means, training firms autonomously control access to the apprenticeship segment of upper secondary education. This proves to be a particular challenge for those pupils who follow lower secondary school tracks. Not disposing of an access certificate to higher education, they have to rely on the vocational education and training system and thus have to rely on the apprenticeship system to achieve an 
upper secondary education degree. The situation on the apprenticeship market is somewhat contradictory: On the one side, training firms deplore that they are not able to find "appropriate" candidates to fill in their positions, while on the other side a consistent number of pupils leave the obligatory school system without being accepted as an apprentice in their preferred occupational field. Official reports characterize this situation as a "mismatch" between the job preferences of the applicants and the open positions (Autorengruppe Bildungsberichterstattung, 2020, p. 157).

Consequently, in 2018 nearly a third of a school leaver cohort do not directly enter an apprenticeship but have to fall back on offers of the so-called "transition system." Transition measures are preparatory courses that do mostly not lead to recognized degrees and function as a "waiting room" (Beicht, 2009) for the labor-market. The existence of this "transition system" has fueled a debate in German education policies and was a central point of contention between employers and the state since the early 2000s, where the former stressed the lack of inclusivity of the apprenticeship system and the potential social and individual costs of "delayed" transitions to work, while the latter stressed the lack of "apprenticeship readiness" (Ausbildungsreife; see Kohlrausch \& Solga, 2012; Ratschinski, 2012) of pupils looking for an apprenticeship.

These discussions have been the main driver for the introduction of integrated, preventive transition policies: In order to reduce the recourse to the so-called transition system and in order to optimize the transition from school to work through reducing so-called "matching problems" on the apprenticeship market, an early, preventive and coordinated stance was to be taken. On the one side, a 2004 corporatist agreement between employers, the Federal Employment Agency and the Federal Government (the Ausbildungspakt) agreed to provide all young people "willing and able to train" with a training offer (Nationaler Pakt für Ausbildung und Fachkräftenachwuchs in Deutschland, 2004, p. 2). At the same time, these reforms where partially driven by the idea that-as the actors of the so-called Ausbildungspakt stated- "many of the vacant apprenticeship positions might have been staffed, if young people were better informed, were able to assess themselves realistically and would fulfill the minimal requirements for taking up an apprenticeship" (Nationaler Pakt für Fachkräftenachwuchs in Deutschland, 2009, author's translation). In 2008, during a conference with the title social mobility through education, the federal government issued the goal to reduce the number of persons without a vocational degree from $17,8 \%$ to $8,5 \%$ until 2015. This was meant to be achieved through making "career guidance in all schools compulsory... with the goal to extend the spectrum of occupational choices" (Bundesregierung, 2008, p. 9). At the same time, the government announced the implementation of a "systematic skill profiling before leaving school in order to smoothen the transition into further schooling and the apprenticeship system through... making young people aware of their strengths and weaknesses and better apprenticeship-readiness" (Bundesregierung, 2008, p. 9). The aim and scope of the envisaged reforms seemed to mimic a policy recommendation by the OECD that, while criticizing the "inefficiency and costliness" (Hoeckel \& Schwartz, 2010, p. 20) of the transition system, also recommends introducing "assessment according to German-wide standards... at 7th grade" (Hoeckel \& Schwartz, 2010, p. 22) and career guidance at an early stage. Following this recommendation, the federal initiative "Educational Chains towards Graduation" (Bildungsketten bis zum Abschluss) of the Ministry for Education, the federal employment agency and the Länder introduced Potenzialanalysen that were made compulsory for all pupils in the 7th and 8th grade. The initiative stressed the leitmotiv "prepare rather than repair" (BMBF, 2010, p. 2, author's translation) and aimed at installing a "preventive and concerted approach in order to avoid the need to repair educational trajectories through measures of the transition system" (BMBF, 2010, p. 2).

The large-scale dissemination of competency testing within the German transition system bears witness to a discursive shift in the framing of youth unemployment, in which the reason for "delayed" transitions to work is re-signified from a structural lack of apprenticeship places to a concern for the optimization of transitions and a lack of knowledge and career self-management of pupils transitioning to work. Garsten and Jacobsson (2004) describe this as a discursive shift from "lack of employment" to a "lack of employability." Lister (2003, p. 430) describes this as a "productivist reordering of social policy" that implies a new glance on the next generation as citizen workers of the future. Early monitoring and profiling (through competency tests) are part and parcel of a social investment approach that aims at "prepar[ing]... rather than repair[ing]" (Hemerijck, 2018, p. 811) and thus requires to identify "youth" based on risk factors prior to the occurrence of a specific life course event. Early intervention is supposed to prevent biographical detours, reduce later costs for the welfare state and to ensure a fast economic self-sufficiency. The view on youth as a "smart investment" is, for instance, reflected in the 2013 coalition agreement that expresses support for the extension of competency assessments: "No young person should be allowed to lose precious time in waiting loops....[W]e want to reach every young person, counselling takes a preventive stance... we will extend the successful initiative Bildungsketten so that as many young people as possible realize their potentials" (CDU et al., 2013, p. 55). Rather than intervening in the market mode of coordination of the vocational training system, the government decided to focus on measures that smoothen the problems of "mismatch" through an intensive scrutiny of cohorts of school leavers through intensive individualized assessment and through 
"introduce[ing] pupils early to choosing a job" (BMBF, 2017, p. 2).

From a Foucauldian perspective, this new kind of transition policies can be seen as a form of biopolitical regulation of youth as "human futures," where the state regulates through "develop[ing] means to identify, train and foster their populations' innate capabilities and behavioral tendencies" (Lee \& Motzkau, 2011, p. 9). Jessop argues that the change from a Fordist to a post-Fordist knowledge economy leads to a new focus of state policies: Rather than focusing on demand side intervention, policies focus on the enhancement of "structural competitiveness of open economies mainly through supply-side intervention and to subordinate social policy to the demands of labor market flexibility" (Jessop, 1993, p. 19). The skills and capacities of the labor force are seen as a central vector of state action. State policies thus increasingly opt for "a policy of growth... focused precisely on one of the things that the West can modify most easily, and that is the form of investment in human capital" (Foucault, 2008, p. 232). In this context, "the problem of control, screening, and improvement of the human capital of individuals, as a function of unions and consequent reproduction, will become actual, or at any rate, called for" (Foucault, 2008, p. 228). This becomes apparent in the policy rationale accompanying the introduction of so-called Potenzialanalysen according to which the problem of "mismatch" between young people's aspirations and the existing labor market opportunities are to be overcome by an early and systematic screening of competencies of all school leavers. In the same vein, authors that analyze the formation of subjects in post-Fordist economies highlight that the focus on competencies increasingly attempts to mobilize the subjectivity and "inner" capacities of whole persons (Traue, 2010) to be mobilized and displayed by workers. In this context, Traue (2010) highlights the central role of practices of testing that are crucial for the visibilization and readability of competencies. The intervention to reform transition policies through a stronger focus on competencies and testing aims to adjust transition policies not only to become an efficient instrument to optimize transitions, but it is also a strategy for the formation of "entrepreneurial" (Bröckling, 2015) and responsible citizens.

\section{Contextualizing the Role of Competency Assessments in German Transition Policies}

Hanson (1994, p. 19) defines tests as "a representational technique applied by an agency to an individual with the intention of gathering information." In the case of competency assessments, the gathered information, as well as the intention, for which that information is used, slightly differs from the intentions of commonly known testing regimes put to use in educational settings. Competency assessments in Germany are not primarily aiming at placement testing (like the classic SAT test or entry testing for universities in the US) but constitute a mix of formative and summative assessment. While officially, competency assessments aim at a pure formative assessment to "encourage students to reflect on themselves" (BMBF, 2015, p. 2; see also Kunert, 2014, p. 32), it also argues that a considerable range of the procedures used for competence testing in the framework of "educational chains" contain summative elements, for instance through providing standard values for different student populations, through employing psychometric vocational tests, and through displaying the fit between personal characteristics and different potential jobs in the final test report handed out to the pupils. On the one side, federal policy documents seem to stress the fact that competency assessments are meant to be purely formative and "should not specify a certain professional direction but open up the gaze to future options and possibilities" (BMBF, 2015, p. 4). On the other side, the concepts of some of the länder at least explicitly define competency assessments as a combination of "scientifically recognized testing procedures, practical tasks to be evaluated, and elements of assessment centers" (MAGS NRW, 2018, p. 29). Until 2018, 13 of the 16 Länder had concluded agreements with the federal state, leading to a wide scale introduction of competency assessments in the German transition system. In order to be eligible for funding by the federal state, the Länder are expected to respect "quality standards" by the federal state (BMBF, 2015). This leads to the fact that the different Länder show a certain heterogeneity in terms of selected programs and concrete content of competency assessment. While Lower Saxony, Saxony, and Rhineland-Palatinate opted for a for a third-party program called "Profil-AC" to be conducted by teachers inside schools, other Länder (for instance North-Rhine Westphalia) allow for a large number of procedures, some provided by larger for-profit providers (HAMET 2 or Peakus), other designed by smaller non-profit organizations to be conducted off school site and selected individually by each school. Other Länder develop their own procedures (Hamburg). As the guidelines of the federal ministry postulate, all procedures have a duration of 1-2 days, containing three to four tasks to be completed alone or in a group, and are inspired by "assessment centers" used in applicant selection by firms and aim at the observation of "competencies" by professionals. Most procedures include some kind of standardized, psychometric test, be it for the assessment of career preferences (Kompo7, Peakus) or even for cognitive abilities (Profil-AC). Many procedures contain instruments for self-assessment and self-reflection, and all of them finish with a personal feedback and the handing out of a competency profile. Competency assessments are not meant to focus on scholarly aptitude, intelligence, or other proxies for educational success. Rather, while the choice of the testing procedures put to use are left to local actors, the federal administration defines five fields of competencies, including "methods and planning competencies, 
social competencies (communication skills, ability to deal with conflict, criticism and teamwork), personal competencies (reliability, flexibility, independence, ability to concentrate) practical skills (dexterity, orderliness, work speed and accuracy)" (BMBF, 2015, p. 3, author's translation) to be evaluated using standardized individual and group tasks (usually consisting in standardized task to be fulfilled in a group, young people are then observed and rated according to a fixed observation schedule). In most procedures, students then have to fill in a self-evaluation form and discuss the test results with the persons establishing the pupils' competence profile. As the name of the program under which competency assessments are funded ("educational chains") suggests, competency testing in 7th or 8th grade is the starting point of a larger network of linked activities of career counselling, short term internships and job-search activities. In this process, the personal competency profile in which the results of the tests are written down is attributed a central role. At least in theory, it links the different stages and events of the educational chain towards a successful transition, from the feedback of the results to parents, to the establishment of "learning contracts" between teachers and pupils based on the profile, up to career counselling outside of school or the use of the competency profile for a job application. In some sense, it "serve[s] as [an] interface between multiple social worlds and facilitate[s] the flow of resources (information, concepts, skills, materials) among multiple social actors" (Roth \& McGinn, 1998, p. 42).

\section{Theory and Methodology: Competency Profiles as Textually Mediated Subjectivation Devices}

Particularly, authors that have analyzed the implicit normative constructions of career guidance policies describe a paradigmatic shift: "While career guidance traditionally has been about job matching, it is now intended to support individuals' employability and encourage them to perform skills and competences....Career guidance is constructed as an asset to support individuals' investment in the self" (Bengtsson, 2011, p. 623). This is also expressed in the "quality standards" regarding competency assessments by the federal state. The latter aims at "not simply testing observable skills and knowledge" (BMBF, 2015, p. 2); rather, they claim to "take a look at the whole person in their respective contexts through biographical approaches" and to "encourage students to reflect on themselves" (BMBF, 2015 , p. 2, author's translation). Technologies of competency testing play a central role in this process. A number of authors have considered the role of standardized testing as a new mode of exercise of power in postdisciplinary societies: As Foucault has shown, the technology of "examination" increasingly supersedes hierarchical surveillance of disciplinary societies and expands from disciplinary institutions and hospitals of the eighteenth century to schools and pedagogical sites such as schools (Foucault, 1979, p. 184). He claims that paralleling the development of the psycho-disciplines, the examination combines "the techniques of an observing hierarchy and those of a normalizing judgement" (Foucault, 1979 , p. 184), that through imposing "on those whom it subjects a principle of compulsory visibility" (Foucault, 1979, p. 187) not only objectifies the individual as a "calculable man" (Foucault, 1979, p. 192), but in which each individual "receives as his status his own individuality, and in which he is linked by his status to the features, the measurements, the gaps, the "marks" that characterize him and make him a "case" (Foucault, 1979, p. 192).

Building on Foucault's work, Lemke (2004) and Bröckling (2015) describe a changing focus in the technologies of testing in post-disciplinary societies. Lemke (2004) points out that historically, with the emergence of testing, staff selection procedures were strongly modelled into the demands of production processes in Fordist economies and focused on "individualized and isolated workers, composed of a finite set of testable qualities, their aim was to assign the appropriate place in the production process" (Lemke, 2004, p. 265). In contrast, new forms of testing, like competency assessments do not operate with pre-established statistical, technical and social norms to be measured, but artificially simulate and anticipate working situations in which candidates are invited to display their authentic self through an open performance (see also Illouz, 2008, p. 66). As Bröckling (2015, pp. 161-162) suggests, these technologies aim, beyond the evaluation of existing characteristics of a person, to the formation of a specific, self-reflective individuality. This view is supported by Kaminski (2013, p. 186) arguing that the subjectivating effects of testing lie in opening spaces of possibility and leading the person to become what they potentially are within the borders of those spaces.

Research in the Foucauldian tradition has thus abundantly shown that contemporary forms of testing play a central role for inculcating a new ethic of desirable self-formation. Tests, so it goes, propose models "for setting up and developing relationships with the self" (Foucault, 1988, p. 29), and are part of those "pedagogies of expertise" (Rose, 1998, p. 93) that lead to the "the inculcation of particular kinds of relations that the human being has with itself" (Rose, 2004, p. 42). In so doing, they partly create what they are supposed to measure (Hacking, 2004; Hanson, 1994). They perform a "construction of identity through assessment" (Reay \& Wiliam, 1999, p. 343). Nevertheless, this field of research has mainly focused on reconstructing the role of testing in an abstract manner. Testing is seen as relevant insofar it contributes expression of a specific "type" (Bröckling, 2015) of subject, that comes into existence by being addressed as such through discourse. Through the focus on discourse, such a perspective does only provide a limited theoretical vocabulary for analyzing the role of concrete material artifacts for subjectivation processes. 
That said, Foucault's work displays an abundant interest in the exercise of power through very concrete technologies and practices (see, e.g., Matthewman, 2013). His detailed analysis of the architecture of the prison, the examination as a special microtechnology of social control, the development of detailed "records, individual dossiers, new classificatory systems and timetables dictating activities to be undertaken" (Foucault, 1979, p. 11) show that Foucault was preoccupied with the concrete tools and technologies through "which subjects are transformed into objects of knowledge within organizational matrixes" (Matthewman, 2013, p. 276). Therefore, I draw on actor-network theory to develop the notion of a "textually mediated subjectivation device." In this sense, the competency profiles analyzed in the next section are to be seen as a special microtechnology that allows to define and classify people and that constitutes the point of "contact between the technologies of domination of others and those of the self" (Foucault, 1988, p. 18).

Actor-network theory focusses on the objects and texts that mediate the practice of testing and highlights how they are interwoven in a network that is made up of humans and things, and that "functions across far flung regions of time and space" (Fenwick, 2010, p. 112). Such a perspective proves particularly useful for the analysis of educational standards such as the diffusion of competency assessments as a specific screening procedure in German transition management. In his analysis of a statewide curriculum reform in the state of Virginia, Nespor (2002) shows how standardized tests act as immutable mobiles, traveling across time and space to "enroll" human as well as non-human entities into a network. Nespor (2002) points to the fact that standardized tests, once settled in a fixed representation link together, mediate massive networks of agents and mobilize a whole series of people and events to align with its forms. This becomes obvious in the case of the so-called "educational chains," where the diffusion of an "assessment according to German-wide standards" (Hoeckel \& Schwartz, 2010, p. 22) happens through a textually mediated enrollment of sites ranging from the practices of testing to those sites, in which the use of the test results is envisaged (schools, career guidance, employers, and finally the pupils).

As Prior (2008, p. 822) suggests, documents, such as the competency profile are not only receptacles of content, but also "active agents in networks of action." As such, they have the capacity to enroll and inscribe human actors into a specific regime of visibility. Firstly, through its specific affordances, its display of information and the way it addresses, configures, and positions the pupils, it invites them to see and to describe themselves through the evaluative vocabulary of the test. In doing so, pupils might come to know themselves as the kind of person that the test is supposed to measure. Furthermore, the competency profile acts as an intermediary, which "embeds a history of network constructions, struggles, and mediations which have settled into one fixed representation" (Fenwick, 2010, p. 123) that allows one to compare and summarize the student population and act upon them politically.

\section{Analyzing Competency Profiles: Methodological Considerations}

Standardized documents such as the competency profile can be thought of as "standardized artifacts" (Wolff, 2004 , p. 284) that bear "institutional traces," allowing to make inferences on the "activities, intentions and ideas of the creators of the document as well as the organizations they represent" (Wolff, 2004, p. 284). Institutional ethnography highlights that texts are an ideal starting point for analyzing "ruling relations" (Smith, 2005) as they regulate local practices through establishing connections to dominant, extra-local political and economic programs: "Texts... are mechanisms for coordinating activity across many different sites... institutional ethnographies are designed to reveal the organizing power of texts, making visible just how activities in local settings are coordinated and managed extralocally" (Devault, 2006, p. 294). These ruling relations do not only operate through prescriptive rules, but the material artefacts themselves carry-as Nicolini (2013, p. 228) puts it:

The script their designers embodied into them, and for this reason, they convey a particular culture of action. As a result, cultural artifacts constitute a means of transmission of social knowledge by carrying inscribed within them objectified norms of cognition, assumptions about how work should be carried out and the purposes of their use.

In the same vein, Latour has coined the term "inscription" (Akrich \& Latour, 1992, p. 259) to designate the fact that material artifacts (such as documents) carry specific action programs inscribed by the designer, the manufacturer, etc. As Roth and McGinn describe (1998, p. 45), while being contingent upon their reading to the context of particular moments of interpretation, inscriptions serve particular interests: "Inscriptions are usually crafted to be relevant to particular purposes," for instance, to "to keep track of people, objects, information, money, organs, and so on." A document suggests specific ways of using it, contains and highlights potentially institutionally relevant categories, and specific local doings and declare them an "institutionally actionable" (Smith, 2005) reality. For the analysis of competency profiles, I am focusing on the programmatic and institutional traces they contain. Competency profiles handed out to the pupils can be conceived of as "institutional scripts" that "streamline[s], organize[s], include[s] and exclude[s] information by instructing staff... to attend to certain themes and categories of information" (Berrick et al., 2018, p. 41). The concept of an institutional script focusses both the encoding of the script into institutional principles as well as its concrete organizational enactment. 
In this article, the competency profile handed out to the pupils after the competency assessment is highlighted. Practices of testing as well as the subsequent uses of the competency profiles are left out, even though they are part of the whole complex of testing practices. The analysis follows a documentary approach and follows Hammersley and Atkinson's (1995) and Charmaz's (2006) suggestions regarding ethnographic research on documents. Additionally, the analysis is informed by ethnomethodological document analysis (Wolff, 2004).

The contribution focusses on the competency profiles as a document (and not their situated use) to display their rationale of construction, their display of information and to show how they address the pupils and construct them as a specific kind of person in the light of the evaluative frameworks of the competency assessment. The analysis is based on 6 competency profiles, including the profiles of those procedures most commonly used in Germany. The analysis shows how the documents take up and translate to the federal standards of the "educational chains" initiative. As a consequence, the analysis focusses on selected sections that are similar in all documents.

\section{Analysis and Results}

The analyzed competency profiles are between 3 to 16 pages in length and very similar in structure. They all contain a cover page with the name of the pupil and the name of the organization that conducted the assessment. The competency profiles are structured into four sections. They all contain a short, written statement on how the pupil fared in different competency areas, a graphic illustration of the five fields of competencies mentioned in the federal standards in term of a quantified scale (mostly from 1 to 5), and a graphic illustration that opposes self-assessment of the pupil with external assessment by the procedure. Most profiles also contain a graphic illustration that opposes the measured competencies of the pupil to the competencies required for different vocational fields. In addition, some profiles contain instructions for further steps and/or additional forms to be filled in and signed by the pupil. The competency profiles start with a cover page (Figure 1). Here, the combination of logos, the title caption and the pupil's name give the document an immensely official make-up and resembles an official diploma that claims, on the

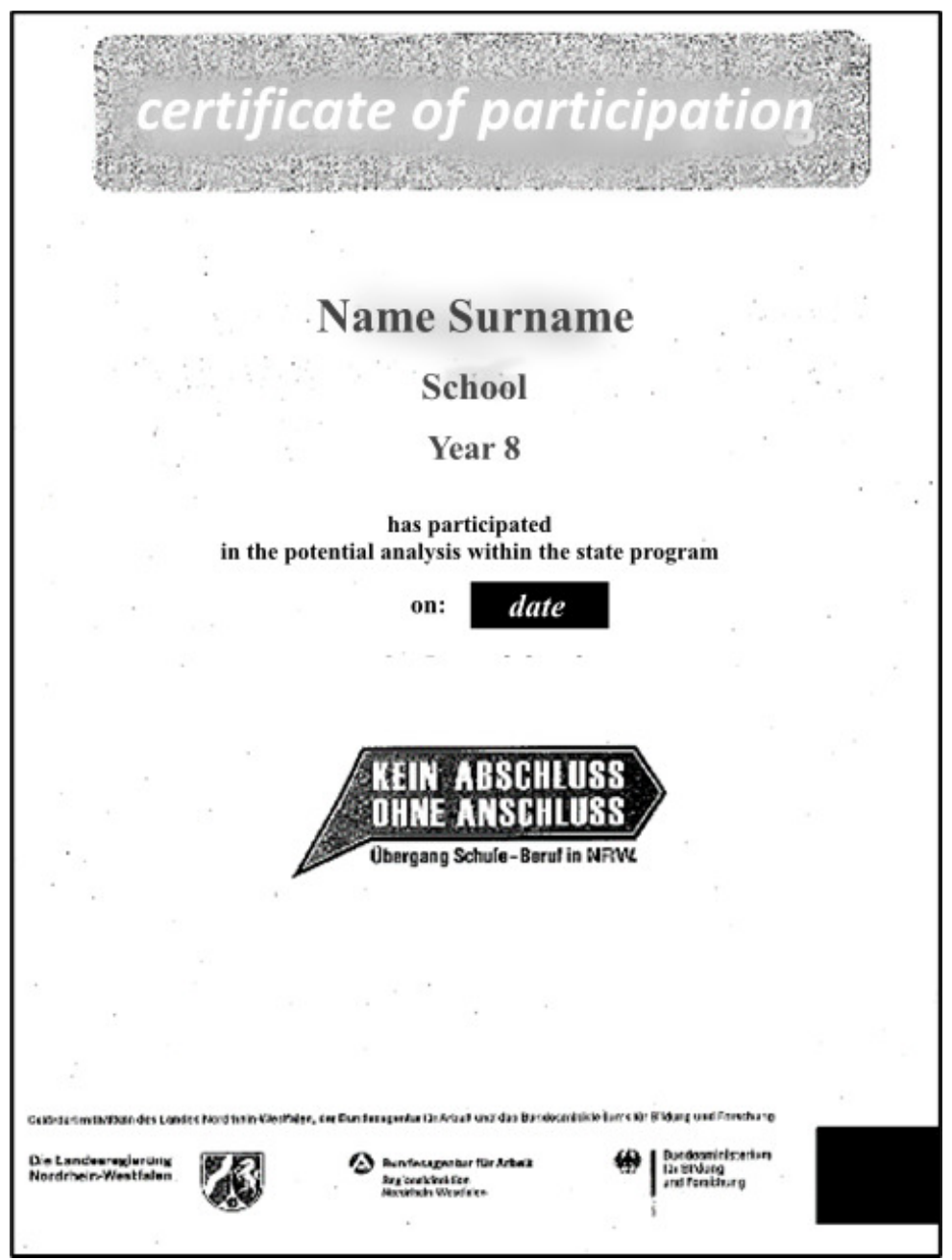

Figure 1. Cover page of a competency profile. 
one hand, epistemic authority, while on the other it is strictly attached to an individual. This indicates that the "ostensible purpose of the text" (Charmaz, 2006, p. 39) seems to be to officially recognized a person as possessing certain qualifications and meeting certain standards. The design of the document suggests that it addresses a "defined circle of legitimate or involved recipients" (Wolff, 2004, p. 284).

Rather than being intended for the use by the individual person (and alleged holder of these qualifications), it is designed for the use in "official" contexts, where the logos of official, recognized institutions serve as warrantors for the validity of the reported content. As tests come with the implicit claim that the tested performance at a specific moment in time can be projected to future situations (Ott, 2011, pp. 158-159) the competency profile serves as an "immutable mobile" (Latour, 1987) that warrants the validity of the test for different actors and that allows the test results to travel across space and time. As such, the competency profile "serve[s] as [an] interface between multiple social worlds and facilitate[s] the flow of resources (information, concepts, skills, materials) among multiple social actors" (Roth \& McGinn, 1998, p. 42). The competency profile constitutes a writing device for "coordinating different actors" (Callon, 2002, p. 210) for instance, vocational counsellors, human resources departments, parents and last but not least, the pupils themselves.

Figure 2 shows the graphic illustration of the five fields of competencies. The different fields of competencies (in the grey field, e.g., social competency) are subdivided in specific competencies (e.g., in the white field: "ability to communicate, ability to work in a team") that are then rated as a numeric value from 1 (low) to 5 (high). This section of the competency profile is particularly telling when asking the analytical question: "What is omitted? What is taken for granted?" (Hammersley \& Atkinson, 1995, pp. 142-143). The numeric display of test results hides considerable information about the context in which the result was obtained, the intentions of actions or the mood of the person while performing the test. The different translations, implied in performing a test (observing, categorizing, scoring, adding up, and writing down), are invisibilized and "blackboxed." Results are displayed as a "mechanically objective" (Daston \& Galison, 1992, p. 82) fact, as the way information is displayed "attempts to eliminate the mediating presence of the observer" (Daston \& Galison, 1992, p. 82).

On the other side, the reduction of information into a numeric value substantially increases the generalizability and the comparability of information. Only a quantified display of information allows the recorded values to be compared, and thus to evaluate the competencies of a person. This process of translating and valuating different, previously incommensurable qualities into a common metric can be called "commensuration" (Espeland \& Stevens, 2008, p. 408). Once commensurated, comparisons are possible, both within the same competency profile (in relation to their other competencies, e.g., student $A$ is a rather "socially competent" person) and between persons (student A disposes of "higher" competencies than student B). It is important to highlight that it is an achievement of the document in the ethnomethodological sense that consists in "making the circumstances of their production invisible" (Wolff, 2004, p. 289).

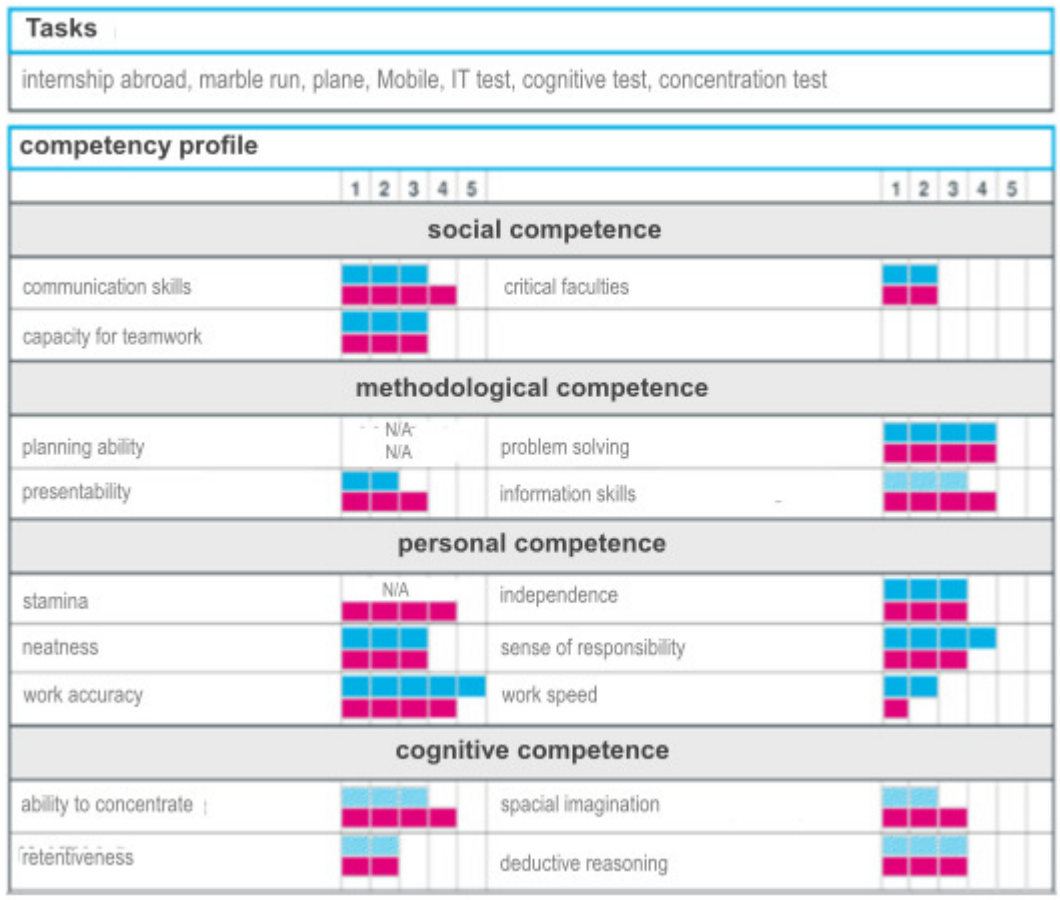

Figure 2. Graphic illustration of competencies in competency profiles. 
A specific feature of the so-called Potenzialanalyse in Germany is that it combines external assessment with self-assessment. This means, after each task during the assessment process, young people are asked to rate themselves. These ratings are also included in the competency profile in the graphic illustration (Figure 2) for each competency field self-assessment of the pupil (blue) with external assessment by the procedure (purple). At a glance, the reader of the document is confronted with a comparative illustration of derogations between the external assessment and the subjective selfappraisal of the person. In this illustration, subjective selfassessment and allegedly objective external assessment by the testing procedure is intertwined. The form transports a specific regime of visibility, that combines a specific way of "being seen" with an invitation to see and apprehend oneself through a specific evaluative matrix. With McLean and Hoskin (1998), one can argue that the form, qua its inscriptions, "configures the user" (McLean \& Hoskin, 1998, p. 529) in a specific manner: The form, as a valid representation of knowledge, maps the pupil in terms of five categories of competencies, constructing an image of an individual who is potentially deficient in terms some of these categories.

The pupil is configured both as an examinee and primary object of grading, as well as a an individual capable and willing to reflect on oneself and to accept the epistemic authority of the test. It invites the user to perform a self-evaluation from the background of the evaluative categories figuring in the form. This applies even more as the official purpose of the analysis of potentials does not consist of a strict test of aptitudes measuring the fit between persons and jobs but aims at "encourage[ing] students to reflect on themselves" (BMBF, 2015, p. 3, author's translation). Pupils are thus not merely expected to receive the results passively. Through self-reflection, they also accept the authority of the external assessment and the obligation to transform themselves. Differences between the "subjective" self-assessment scores and the "objective" test scores demarcate deviance from the norm. This deviance from the norm becomes the object of an internal process of self-reflection. As the next figure shows, pupils are asked to individually reflect on their strengths and weaknesses, as identified in the competency assessment. The document displays a normalizing judgement that "makes it possible to qualify, to classify and... establishes over individuals a visibility through which one differentiates them and judges them" (Foucault, 1979, p. 184).

Once identified, the deviance from the norm can be made object of institutional scrutiny. Deviance is made "institutionally actionable" (Smith, 2005) for social workers, the school or career guidance professionals. As it is stated in a guideline of the Bildungsketten initiative for so-called "career start counsellors" (Berufseinstigsbegleiter*innen), "the results of the Potenzialanalyse should form the basis for the individual work with the young persons. They should give hints on what competences can be developed through individual support" (BMBF, 2013, p. 2, author's translation). Career start counsellors are financed by the federal employment agency and provide individual counselling in schools before graduation for young persons in "special need of support" according to the definition advocated by German legislation on employment promotion (Article 49). At least implicitly, the divergence of self-assessment and external assessment in a competency profile is equated with a legal category of being in need of special support. The production of a space of visibility of deviation from the norm thus has a double performative function. Firstly, it opens up a space of possibilities for the treatment of those young persons who bring in low competences, and more importantly, those whose self-assessment does not (yet) correspond to the external assessment. Secondly, it delineates a space of possibilities and restrictions for the internal reflection on future biographical pathways a young person may legitimately hold.

This performative aspect of the competency profile also becomes visible in its last section. Most profiles contain instruction for further use and additional forms to be filled in and signed by the pupil. The section called "Next Steps After the Potential Assessment" mostly figures at the very end of the competency assessment and provides information on the intended use of the document and the way it is transferred into successive practices. The document is structured into three sections deemed to be filled out by the pupil. The first section opens with the question: The potential assessment shows what your strengths are. What are you already particularly good at? The second section begins with the question: What should you work on in the future? It is telling that the first and second questions do not explicitly refer to the results described on the previous pages but leaves it to the pupils to judge by themselves which of the described competencies are to be evaluated as "strengths" and "weaknesses." As such, the completion of the form invites the pupil to an introspective selfexploration, a form of self-reflection that leads to choosing a specific evaluative vocabulary for self-description. The form invites to a valuation of the self from the background of a prospective process of self-discovery, and it fosters a specific, future-oriented, strategic posture towards oneself.

The subsequent section of the document (Figure 3) asks the student to write down three professional fields they want to explore based on the results of the assessment of potentials: "The next step of your personal career guidance process consist of the exploration of different occupational fields: Which occupational field do you want to explore? Please consider the results of the potential analysis" (from the competency profile). The first part of the sentence frames the choice of a future profession as a personal, individual matter to be constructed by the individual, and highlights its processual, open-ended character (career guid- 


\section{Your next steps after the potential assessment}

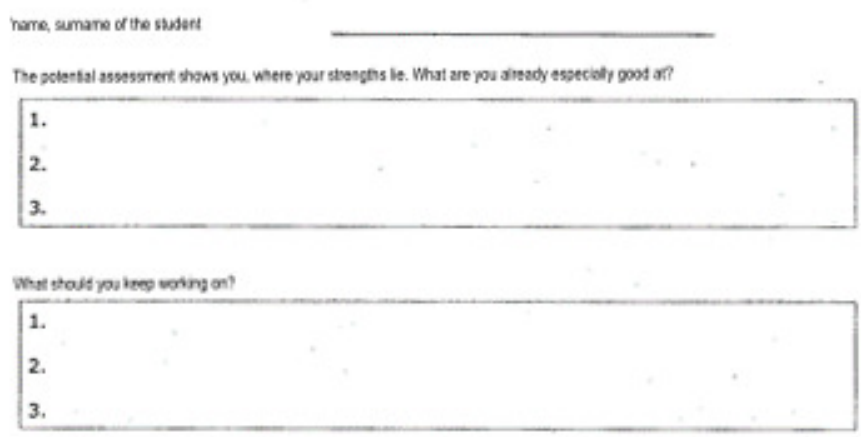

Next up on your personal vecabond onentafon process is the occupatonal fidd euploration. Which Selds would you live to explore? Think about the results $\alpha$ your potential assessmert.

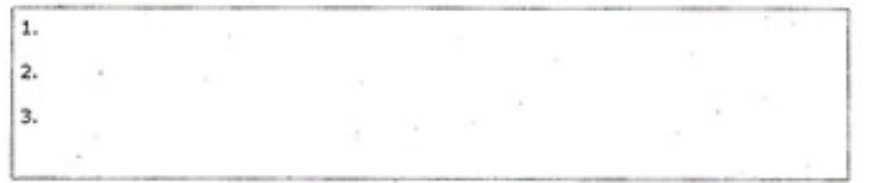

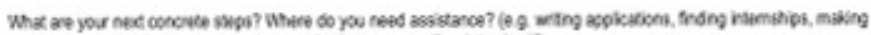

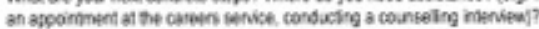

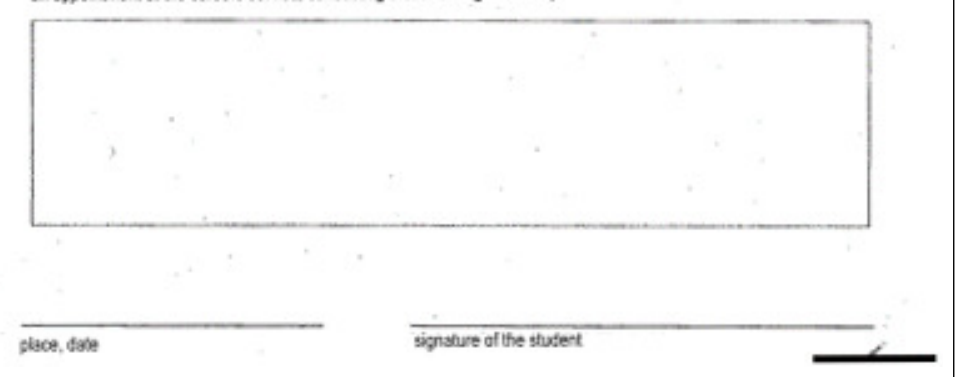

Figure 3. Next steps after the competency assessment.

ance process) consisting of clearly defined consecutive steps. It re-inscribes this personal matter into a specific institutionalized event (the exploration of occupational fields are mandatory internships in the framework of the Bildungsketten program organized by the schools). The seemingly "open-ended," individualized process is channeled into a very specific and concrete desirable outcome (the mentioning of three occupational fields). The phrasing leaves no doubt that the results of the test are expected to be considered within the formally free and self-guided reflection process.

These results show that the test does not primarily aim at classifying individuals according to fixed statistical norms and matching their characteristics to specific job positions (otherwise, it would authoritatively propose a vocational field to be explored). Much more, it configures the user as a "responsible self-observer" (Born \& Jensen, 2010, p. 328) that acts upon themselves. While the range of possible vocational choices is not authoritatively prescribed by the test, it positions the choosing individual to responsibly justify vocational choices with reasonable arguments, respecting his own personhood ("What are you good at?"), but also with respect to the external evaluation ("Please consider the results of the potential analysis"). The document contains a field for a signature of the pupil, conferring an official status to the document. The contractual form as an "enforceable exchange of promises" (Yeatman, 1998, p. 230), potentially holds the signing party accountable for the future, and the document may be invoked by different actors and institutions for exactly that purpose.

\section{Discussion and Conclusion}

The exemplary analysis of competency profiles, aimed at reconstructing their rationale of construction, the way information is displayed and finally, the ways in which it configures its readers. I have argued that the document addresses the pupil and constructs them as a specific kind of person in the light of the evaluative framework of the test. The document addresses the reader as a "responsible self-observer" (Born \& Jensen, 2010, p. 328), that acts upon themselves. These findings reflect theoretical accounts on testing that focus on their performative nature: Through enforcing a specific regime of visibility, tests "performatively produce what they pretend 
to measure" (Lemke, 2004, p. 267). As Hanson (1994, p. 4) puts it, the contemporary individual is "not so much described by tests as constructed by them."

The competency profile invites pupils to see and to describe themselves through the evaluative vocabulary of the test and, as such, come to know themselves as person disposing of or lacking the competencies measured. The specific performance of the competency profile consists in making the circumstances of its production (the testing process itself) invisible, and of making comparable different pupils through quantified commensuration. As such, they also provide a specific form of knowledge that is used both for the control, screening, and improvement of human capital of individuals by government actors, and for fostering processes of biographic self-optimization of pupils. Furthermore, as the analysis has shown, the competency profile potentially serves as an "immutable mobile" (Latour, 1987) that allows the test results to travel across space and time. As part of the larger actor network of the "educational chains" initiative, it links together and mediates a whole series of people and events, potentially coordinating the vocational choice processes of young persons with the institutional calendars and standardized career counselling activities of different organizations.

Our results demonstrate that competency profiles construct the process of choosing a job as an "individualized project of the self" (Dahmen, 2021, p. 228). In doing so, competency assessments potentially contribute to the reproduction of inequalities in post-secondary education through delegating "cooling out" processes from institutional gatekeepers to the interiority of persons. As described in the first section, in vocational training system pupils from the lower tracks of the school system (have to) adapt their job aspiration to certain possibilities when arriving at the end of obligatory schooling (Heckhausen \& Tomasik, 2002). The implicit message of the competency profile confirms the ideology of a "free choice" of vocational options. This invisibilizes structural barriers of the vocational training system, characterized by a restricted number of apprenticeship places in the most popular occupational fields.

While the pupil is addressed as formally free to choose possible occupational fields based on their inclinations, they are also asked to internalize the limitations of the external assessment, as proposed by the competency assessment. In doing so, the instrument "competency profile" potentially plays an important role for processes of "cooling out" (Walther, 2015). On the one side, it affirms the social value of individualized personhood and autonomous job choice in which each and every one can realize their very own inclinations and potentials, on the other side, it strives towards the legitimation of unequal positions of members of a society. Tests and testing are part of a "positivist meritocracy" (Hanson, 1994, p. 272) that promises a quasi-scientific placement of persons according to ability. The "mechanical objectivity" (Daston \& Galison, 1992, p. 82) of competency assess- ments does give a scientific guise to the sorting processes at the end of obligatory schooling.

Cooling out processes imply that "that individuals do not only ascribe failure in achieving full social participation to own failure but accept lower social positions as adequate for themselves because and appropriate to their capacities" (Walther, 2015, p. 29). The competency assessments supply the subject with a "a new framework in which to see himself and judge himself" (Goffman, 1952, p. 456) and in which he comes to see himself as a person that does (not) dispose of specific competencies. Competency profiles spell out the space of the possible and the young persons (potentially) align their selfassessment to these categories: "As I am this or that kind of person, I might consider choosing this or that job" (from the competency profile).

The instrument invites the young person to apply the epistemic matrix of the instrument into their own selfscrutiny, and to align and synchronize the classifications of the instrument with their own self-understanding. The novelty of these new forms of subjectivation is-in comparison to cooling out processes performed by gatekeepers and teachers - that the limitation of structural possibilities (e.g., what possible jobs enter the larger field of envisioned futures) does not happen in a prescriptive way. Rather, the structure of competency tool strives towards a subjective incorporation of structural limitations. The adaptation of the "possible" to the "probable" (Bourdieu, 1990), the coupling between what you "want" and "what you can get" operates through a process of textually mediated self-formation. As Hanson (1994, p. 272) puts it, tests "not only condition the expectations and promises that society holds out for various categories of people but also color the expectations and prospects that individuals imagine for themselves."

\section{Acknowledgments}

I thank Joshua Brix (Bielefeld University) for language editing and Sabine Kaiser (Bielefeld University) and Marc Thielen (Leibniz University Hannover) for useful discussions. I also thank the editors of this thematic issue as well as three anonymous reviewers for useful comments on a previous version of the manuscript.

\section{Conflict of Interests}

The author declares no conflict of interests.

\section{References}

Akrich, M., \& Latour, B. (1992). A summary of a convenient vocabulary for the semiotics of human and nonhuman assemblies. In W. Bijker \& J. Law (Eds.), Shaping technology/Building society studies in sociotechnical change (pp. 259-264). The MIT Press.

Alasuutari, M., Kelle, H., \& Knauf, H. (Eds.). (2020). Introduction: The ambivalence of documentation in insti- 
tutional contexts of early childhood. In Documentation in institutional contexts of early childhood (pp. 1-12). Springer VS.

Autorengruppe Bildungsberichterstattung. (2020). Bildung in Deutschland 2020. Ein indikatorengestützter Bericht mit einer Analyse zu Bildung in einer digitalisierten Welt [Education in Germany 2020. An indicator-based report with an analysis on education in a digitalized World]. WBV.

Beicht, U. (2009). Verbesserung der Ausbildungschancen oder sinnlose Warteschleife. Zur Bedeutung und Wirksamkeit von Bildungsgängen am Übergang SchuleBerufsausbildung [Improving the chances for apprenticeships or futile waiting loop? On the significance and efficacy of educational programs on the schoolapprenticeship transition] (BIBB-Report No. 11(09)). Bundesinstitut für Berufsbildung.

Bengtsson, A. (2011). European policy of career guidance: The interrelationship between career selfmanagement and production of human capital in the knowledge economy. Policy Futures in Education, 9(5), 616-627.

Berrick, J. D., Dickens, J., Pösö, T., \& Skivenes, M. (2018). Care order templates as institutional scripts in child protection. A cross-system analysis. Children and Youth Services Review, 84(1), 40-47.

Born, A. W., \& Jensen, P. H. (2010). Dialogued-based activation-A new "dispositif"? International Journal of Sociology and Social Policy, 30(5/6), 326-336.

Bosančić, S., Pfahl, L., \& Traue, B. (2019). Empirische Subjektivierungsanalyse: Entwicklung des Forschungsfeldes und methodische Maximen der Subjektivierungsforschung [Empirical subjectivation analysis: Development of the field of research and methodological maxims of subjectivation research]. In S. Bosančić \& R. Keller (Eds.), Diskursive Konstruktionen. Theorie und Praxis der Diskursforschung [Discursive constructions. Theory and practice of discourse research] (pp. 135-150). Springer VS.

Bourdieu, P. (1990). The logic of practice. Stanford University Press.

Bröckling, U. (2015). The entrepreneurial self. Fabricating a new type of subject. Sage.

Bundesministerium für Bildung und Forschung. (2010). Vereinbarung zur Durchführung der Initiative $A b$ schluss und Anschluss-Bildungsketten bis zum Ausbildungsanschluss. Anlage 1 [Agreement on the conduct of the initiative graduation and connectionEducational chains up until the beginning of an apprenticeship. Attachment 1]. https://www. bildungsketten.de/_media/Bildungsketten_ Vereinbarung_NRW_Anlage_1.pdf

Bundesministerium für Bildung und Forschung. (2013). Konzept des Bundes zur Weiterentwicklung und Ausweitung der Initiative Abschluss und AnschlussBildungsketten bis zum Ausbildungsabschluss [Federal concept for the development of the initiative educational chains]. https://www.bildungsketten.
de/_media/Bildungsketten_Vereinbarung_NRW_ Anlage_1.pdf

Bundesministerium für Bildung und Forschung. (2015). Qualitätsstandards des BMBF zur Durchführung von Potenzialanalysen zur Berufsorientierung 2015 [Quality standards of the BMBF on the conduct of potential analyses of vocational orientation 2015]. https://www.bildungsketten.de/_media/

Qualitaetsstandards_des_BMBF_zur_

Durchfuehrung_von_Potenzialanalysen_2015.pdf

Bundesministerium für Bildung und Forschung. (2017). Talente entdecken. Handlungsleitlinien zur Durchführung von Potentialanalyse für die Berufsorientierung [Discovering talents. Guiderlines for the conduct of potential analysis in vocational orientation]. www.bmbf.de/upload_filestore/pub/Talente_ entdecken.pdf

Bundesregierung. (2008). Aufstieg durch Bildung. Die Qualifizierungsinitiative für Deutschland [Advancement through education. The qualification initiative for Germany].

Callon, M. (2002). Writing and (re)writing devices as tools for managing complexity. In A. Mol \& J. Law (Eds.), Complexities. Social studies of knowledge practices (pp. 191-218). Duke University Press.

CDU, CSU, \& SPD. (2013). Deutschlands Zukunft Gestalten: Koalitionsvertrag zwischen CDU, CSU und $S P D$, 18. Legislaturperiode vom 27. November 2013 [Designing Germany's future: Coalition contract between CDU, CSU and SPD, 18th legislation period from 27 November 2013]. Berlin.

Charmaz, K. (2006). Constructing grounded theory: A practical guide through qualitative analysis. Sage.

Dahmen, S. (2021). Regulating transitions from school to work. An institutional ethnography of activation work in action. transcript.

Daston, L., \& Galison, P. (1992). The image of objectivity. Representations, 40, 81-128.

Devault, M. L. (2006). Introduction: What is institutional ethnography? Social Problems, 53(3), 294-298.

Egbert, S. (2018). (Hoch-)Begabung messen? Programmatische Überlegungen aus testsoziologischer Perspektive [Measuring (high) aptitude? Programmatic ideas from a (test-related) sociological perspective]. In A. Böker \& K. Horvath (Eds.), Begabung und Gesellschaft: Sozialwissenschaftliche Perspektiven auf Begabung und Begabtenförderung [Aptitude and society: Perspectives from social sciences on aptitude and scholarship systems] (pp. 117-137). Springer VS.

Espeland, W. N., \& Stevens, M. L. (2008). A sociology of quantification. Archives Européennes de Sociologie/European Journal of Sociology/Europäisches Archiv für Soziologie, 49(3), 401-436.

Fenwick, T. J. (2010). (Un)doing standards in education with actor-network theory. Journal of Education Policy, 25(2), 117-133.

Foucault, M. (1979). Discipline and punish. Vintage 
Books.

Foucault, M. (1988). Technologies of the self. In H. Martin, H. Gutman, \& P. H. Hutton (Eds.), Technologies of the self: A seminar with Michel Foucault (pp. 16-49). Tavistock.

Foucault, M. (2008). The birth of biopolitics: Lectures at the Collège de France 1978-1979. Palgrave Macmillan.

Garsten, C., \& Jacobsson, K. (2004). Learning to be employable: New agendas on work, responsibility, and learning in a globalizing world. Palgrave Macmillan.

Gaupp, N., Geier, B., Lex, T., \& Reißig, B. (2011). Wege in Ausbildungslosigkeit. Determinanten misslingender Übergänge in Ausbildung von Jugendlichen mit Hauptschulbildung [Ways towards not undergoing formal vocational training. Determining factors of miscarrying transitions of youths with lower school degrees]. Zeitschrift für Pädagogik, 57(2), 173-186.

Goffman, E. (1952). On cooling the mark out: Some aspects of adaptation to failure. Psychiatry, 15(4), 451-463.

Hacking, I. (2004). Between Michel Foucault and Erving Goffman: Between discourse in the abstract and face-to-face interaction. Economy and Society, 33(3), 277-302.

Hammersley, M., \& Atkinson, P. (1995). Ethnography: Practices and principles. Routledge.

Hanson, F. A. (1994). Testing testing: Social consequences of the examined life. University of California Press.

Heckhausen, J., \& Tomasik, M. J. (2002). Get an apprenticeship before school is out: How German adolescents adjust vocational aspirations when getting close to a developmental deadline. Journal of Vocational Behavior, 60(2), 199-219.

Hemerijck, A. (2018). Social investment as a policy paradigm. Journal of European Public Policy, 25(6), 810-827.

Hoeckel, K., \& Schwartz, R. (2010). OECD reviews of vocational education and training: A learning for jobs review of Germany 2010. OECD Publishing.

Illouz, E. (2008). Saving the modern soul. Therapy, emotions, and the culture of self-help. University of California Press.

Jessop, B. (1993). Towards a Schumpeterian workfare state? Preliminary remarks on post-Fordist political economy. Studies in Political Economy, 40(1), 7-39.

Kaminski, A. (2013). Wie subjektivieren Prüfungstechniken? Subjektivität und Möglichkeit bei William Stern und Martin Heidegger [How do testing techniques cause subjectivation? Subjectivity and possibility with William Stern and Martin Heidegger]. In T. Alkemeyer, A. Gelhard, \& N. Ricken (Eds.), Techniken der Subjektivierung [Techniques of Subjectivation] (pp. 173-187). W. Fink.

Kelle, H., Seehaus, R., \& Bollig, S. (2015). Child health records as socio-material instruments of distributing responsibility. A comparative analysis of paediatric documents from Austria, England and Germany. Children \& Society, 29(3), 184-197.

Kohlrausch, B., \& Solga, H. (2012). Übergänge in die Ausbildung: Welche Rolle spielt die Ausbildungsreife [Transtitions into apprenticeship: What role does 'apprenticeship maturity' play]? Zeitschrift für Erziehungswissenschaft, 15(4), 753-773.

Kunert, C. (2014). Die Potenzialanalyse im Berufsorientierungsprogramm des BMBF. Grundlagen und Herausforderungen [The potential analysis in vocational orientation programs of the BMBF. Basics and challenges]. Zeitschrift des Bundesinstituts für Berufsbildung, 43(20155), 30-33.

Latour, B. (1987). Science in action: How to follow scientists and engineers through society. Harvard University Press.

Lee, N., \& Motzkau, J. (2011). Navigating the bio-politics of childhood. Childhood, 18(1), 7-19.

Lemke, T. (2004). Test. In U. Bröckling, S. Krassmann, \& T. Lemke (Eds.), Glossar der Gegenwart [Glossary of the present] (pp. 263-270). Suhrkamp.

Lister, R. (2003). Investing in the citizen-workers of the future: Transformations in citizenship and the state under New Labour. Social Policy \& Administration, 37(5), 427-443.

Matthewman, S. (2013). Michel Foucault, technology, and actor-network theory. Techné: Research in Philosophy and Technology, 17(2), 274-292.

McLean, C., \& Hoskin, K. (1998). Organizing madness: Reflections on the forms of the form. Organization, 5(4), 519-541.

MAGS NRW. (2018). Kein Abschluss ohne AnschlussÜbergang Schule/Beruf in NRW. Zusammenstellung der Instrumente und Angebote [No graduation without connection-School-to-work transitions in Northrhine-Westphalia. Compilation of instruments and proposals]. Ministerium für Arbeit, Gesundheit und Soziales des Landes Nordrhein-Westfalen. www. mags.nrw/broschuerenservice

Nationaler Pakt für Fachkräftenachwuchs in Deutschland (2009). "Ausbildungsreife sicherstellenBerufsorientierung stärken": Vereinbarung der Partner des Nationalen Paktes für Ausbildung und Fachkräftenachwuchs in Deutschland, der Bundesagentur für Arbeit und der Integrationsbeauftragten mit der Kultusministerkonferenz ["Securing apprenticeship maturity-Strengthening vocational orientation": Agreement of the partners of the national pact for apprenticeships and young skilled workers in Germany, the national employment office and the integration commissary with the conference of culture ministers]. http://www.kmk.org/fileadmin/ veroeffentlichungen_beschluesse/2009/2009_06_ 19-Ausbildungsreife-Berufsorientierung.pdf

Nationaler Pakt für Ausbildung und Fachkräftenachwuchs in Deutschland. (2004). Gemeinsame Erklärung der Partner des Ausbildungspaktes und der Bundesagentur für Arbeit [Common declaration of 
the partners of the pact and the federal emplyment office]. http://www.zdh.de/presse/ pressemeldungen/gemeinsame-erklaerung-derpartner-des ausbildungspaktes-und-derbundesagentur-fuer-arbeit.html

Nespor, J. (2002). Networks and contexts of reform. Journal of Educational Change, 3, 365-382.

Nicolini, D. (2013). Practice theory, work, and organization: An introduction. Oxford University Press.

Ott, M. (2011). Aktivierung von (In-)Kompetenz: Praktiken im Profiling-Eine machtanalytische Ethnographie [Activation of (in-)competence: Practices of profiling-A power-analyzing ethnography]. UVKVerlagsgesellschaft.

Piopiunik, M., \& Ryan, P. (2001). Improving the transition between education/training and the labour market: What can we learn from various national approaches? (EENEE Analytical Report 13). European Expert Network on Economics of Education.

Preite, L. (2019). Jugendliche Handlungsfähigkeit wider die Praktiken des Cooling-Out: Eine Fallstudie am Beispiel von drei männlichen Jugendlichen im Schweizer Übergangsregime [Youth agency against cooling out practices: A case study of three young males in the Swiss transition regime]. ZSE Zeitschrift für Soziologie der Erziehung und Sozialisation, 39(4), 384-399.

Prior, L. (2008). Repositioning documents in social research. Sociology, 42(5), 821-836.

Ratschinski, G. (2012). Verdient die "Ausbildungsreife" ihren Namen? Anmerkungen zu einer neuen Rubrik für alte Klagen [Does 'apprenticeship maturity' deserve its name? Remarks on a new category of familiar complaints]. In A. Steuber \& G. Ratschinski (Eds.), Ausbildungsreife [Apprenticeship maturity] (pp. 21-31). Springer.
Reay, D., \& Wiliam, D. (1999). 'I'll be a nothing': Structure, agency and the construction of identity through assessment. British Educational Research Journal, 25(3), 343-354.

Rose, N. (1998). Inventing ourselves: Psychology, power, and personhood. Cambridge University Press.

Rose, N. (2004). Governing the social. In N. Gane (Ed.), The future of social theory (pp. 167-185). Continuum International Publishing Group.

Roth, W. M., \& McGinn, M. K. (1998). Inscriptions: Toward a theory of representing as social practice. Review of Educational Research, 68(1), 35-59.

Smith, D. E. (2005). Institutional ethnography: A sociology for people. Rowman Altamira.

Stobart, G. (2008). Testing times: The uses and abuses of assessment. Routledge.

Traue, B. (2010). Kompetente Subjekte: Kompetenz als Bildungs- und Regierungsdispositiv im Postfordismus [Competent subjects: Competence as a dispositive of education and administration within post-Fordism]. In T. Kurtz \& M. Pfadenhauer (Eds.), Soziologie der Kompetenz [Sociology of competence] (pp. 49-67). Springer.

Walther, A. (2015). The struggle for realistic career perspectives: Cooling-out versus recognition of aspirations in school-to-work-transitions. Italian Journal of Sociology of Education, 7(2), 18-42.

Wolff, S. (2004). Analysis of documents and records. In U. Flick, E. von Kardoff, \& I. Steinke (Eds.), A companion to qualitative research (pp. 284-289). SAGE.

Yeatman, A. (1998). Interpreting contemporary contractualism. In H. Dean \& B. Hindess (Eds.), Governing Australia: Studies in contemporary rationalities of government (pp. 227-241). Cambridge University Press.

\section{About the Author}

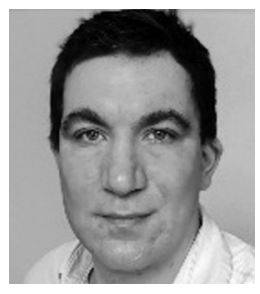

Stephan Dahmen, born in 1982, is a Postdoctoral Researcher at the Faculty of Educational Science at Universität Bielefeld, Germany. His current research covers organizational ethnography in human service organizations and education, social inequalities in education, social work and social policy, child protection, the transformations of contemporary youth and childhood and qualitative research methods. 